\title{
Proposing Accountability Index for Indonesia's Local Government
}

\author{
Dyah Setyaningrum ${ }^{1 *}$ \\ ${ }^{1}$ Faculty of Economics and Business, Universitas Indonesia, Depok 16424, Indonesia \\ *dsetyani@ui.ac.id
}

\begin{abstract}
The purpose of the study is to develop a comprehensive accountability index for Indonesia's local governments and to provide evidence regarding the relationship between an accountability index and corruption. We use data from a local government performance report from 2011-2014, identifying several indicators that match the accountability criteria. Principal component analysis is used to reduce twelve variables to the following three major components of accountability: administrative accountability, report timeliness, and financial accountability. From these three components, we develop an accountability index that represents a comprehensive measurement of local government accountability. The result of the multiple regression test shows that a higher accountability index is associated with lower corruption. The important implication of the study is that local governments can measure their level of accountability using a score from the Local Government Performance Report. Moreover, local governments are encouraged to increase their accountability, especially their administrative and financial accountability, as this has proven to reduce corruption. The accountability index proposed in this study can be one of the best alternatives for measuring accountability rather than using a single measure.
\end{abstract}

Keywords: Accountability, Accountability Index, Corruption, Local Government, Principle Component Analysis.

\section{INTRODUCTION}

The importance of implementing good public governance is one of the bureaucratic reform missions of the Indonesian Government ${ }^{1}$. The principle of good public governance is deemed to be important because it is believed to be vital in providing an excellent service to the community. In 2014, the International Federation of Accountants (IFAC) and the Chartered Institute of Public Finance and Accountancy (CIPFA) released the International Framework: Good Governance in the Public Sector ${ }^{2}$. Based on this framework, governance in the public sector is defined as the arrangements put in place to ensure that the intended outcomes for stakeholders are outlined and achieved. In Indonesia, the National Committee of Governance Policy (KNKG) set out the following five principles of good public governance: democracy, transparency, accountability, culture of law and fairness and equality $^{3}$. This study will focus on the accountability aspect of good public governance. Why is accountability extremely important? The public sector is normally responsible for using a significant proportion of the resources raised through taxation to provide services to citizens. Public sector entities are accountable not only for how much they spend, but also for how they use the resources under their stewardship ${ }^{2}$. This includes accountability for their output, both positive and negative, and for the outcomes achieved. In addition, they have an overarching responsibility to serve the public interest in adhering to the requirements of legislation and government policies.

The government's accountability consists of financial accountability and performance accountability ${ }^{4}$. Good financial accountability is observable from the unqualified audit opinion provided by the Supreme Audit Agency (BPK). Based on the summary of BPK's audit report, in the last five years (2011-2015), audit opinion for Indonesia's local government financial statement shows an improvement, but this condition is still below the target of bureaucratic reform ${ }^{5}$. Meanwhile, in respect of performance accountability, based on the result of the performance audit, in general, local government performance is not fully effective.

From the above evidence, it is clear that there is still major room for accountability improvement. This study will focus on developing a comprehensive accountability index for Indonesia's local governments using data from the Ministry of Internal Affairs' score in respect of local government performance (EKPPD) from 2011 to 2014. The case of Indonesia is very interesting, not only because it is a developing country with severe corruption, but also because in the future Indonesia is expected to have the largest economy in Southeast Asia. A previous study proposed the measurement of an accountability index for government agencies in Indonesia by utilizing several accountability indicators ${ }^{6}$. This study proposes an accountability index and presents a figure representing local government accountability from 2011 to 2014. Using the figure, the study will attempt to analyze each local government's strengths and weaknesses in respect of accountability. The data for developing the accountability index uses local government performance indicators from the local governance performance report (EKPPD) compiled by the Ministry of Internal Affairs. In order to provide further evidence of the relationship between accountability and corruption, we will also conduct a test of the accountability index with regard to corruption to 
see whether there any negative relationships between accountability and corruption.

This study is very important for two main reasons: (1) it will develop a comprehensive measure of each local government's accountability, and (2) it will provide evidence of the relationship between accountability and corruption in a developing country so that local governments will make proactive efforts to combat corruption by improving their accountability.

The remainder of this study proceeds as follows: Section II briefly explains the literature review, Section III discusses the research method, and this is followed by the results and a discussion in Section IV. Section V concludes the study with implications and suggestions for further research.

\section{LITERATURE REVIEW}

The agency theory describes the possible conflict in the relationship between agents and principals ${ }^{7}$. The agency relationship also occurs in the governmental public sector where the public (voters) are the principals who delegate authority to the government acting as an agent in the public sector decision-making process. Agency conflicts can also occur when governments adopt policies that only benefit themselves (or groups) and sacrifice public interests and welfare. One of the mechanisms that can be used to prevent any deviant action from agents is the implementation of good public governance . $^{8}$.

Accountability is one of the important principles of good public governance. Accountability cannot only be understood as an obligation to prepare and report the use of funds (budget), it must also evaluate the benefit of the program to community welfare. A comparison of an accountability index measurement has been conducted in several countries, such as Malaysia, Canada and the Netherlands. In general, all three of these countries measure both financial accountability and performance accountability ${ }^{6}$. Previous research only used a single indicator to measure accountability; for example, using a follow-up to an audit recommendation ${ }^{9,10}$ or audit findings ${ }^{11,12}$.

Corruption is a term with many meanings. Most broadly, it can be defined as the misuse of office for unofficial ends. Corruption equals monopoly plus discretion minus accountability or, put another way, one (organization/individual) will tend to be corrupt when one has a monopoly of power, has the discretion to decide who will benefit from such power, and is not accountable ${ }^{13}$. The problem of corruption is more severe in developing countries than in their developed counterparts ${ }^{14}$. Weak law enforcement together with excessive government interventions and discretionary spending, as well as non-transparent procedures, are the main factors that nourish pervasive corruption in developing countries ${ }^{15}$. A study conducted in Vietnam found that higher levels of transparency, participation and accountability were associated with lower levels of corruption ${ }^{16}$. This result implies that good governance involves effective anti-corruption strategies, especially in developing countries ${ }^{17,18}$.

\section{RESEARCH METHOD \\ Sample}

Purposive sampling is used to select the sample. The sampling criteria cover local governments that have complete data for the period 2010-2015. Data sources are obtained from BPK, the Ministry of Internal Affairs and the Corruption Eradication Commission (KPK). The data consists of: (1) audited local government financial statements; (2) a score of local government performance (EKPPD), and (3) the number of public complaints about corruption per local government.

\section{Developing Accountability Index}

The accountability index is developed from the score of local government performance (EKPPD) from the Ministry of Internal Affairs. The performance composite index (EKPPD) comprises a performance achievement index $(95 \%)$ and a conformity assessment index (5\%). The indicators of the accountability index along with the measurement from the EKPPD are presented in Table 1. We use principal component analysis (PCA) to reduce the indicators to one or a few components that can explain the research construct ${ }^{19}$.

\section{RESULTS AND DISCUSSIONS \\ Principle Component Analysis}

Principal component analysis (PCA) reduces the twelve variables of accountability to three components. The breakdown of the three components is shown in Table 2. Based on the result, the accountability index can be broken down into: 1) administrative accountability, 2) report timeliness, and 3) financial accountability. 
Table.1. Indicator of Accountability Index

\begin{tabular}{|c|c|c|}
\hline No & Indicator & Measurement \\
\hline 1. & Audit Opinion & $\begin{array}{l}\text { 4=Unqualified; } 3=\text { Qualified; } \\
\text { 2=Disclaimer; } \\
\text { 1=Adverse }\end{array}$ \\
\hline 2. & Submission of LPPD according to Government Decree No 3/2007 & $\begin{array}{l}2=\text { On time } ; 1=\text { Other; } \\
0=\text { No Information }\end{array}$ \\
\hline 3. & Submission of Financial Statement according Government Decree No 8/2006 & $\begin{array}{l}2=\text { On time } ; 1=\text { Other; } \\
0=\text { No Information }\end{array}$ \\
\hline 4. & Budget (APBD) enactment & $\begin{array}{l}2=\text { On time } ; 1=\text { Other; } \\
0=\text { No Information }\end{array}$ \\
\hline 5. & Submission of Performance Report according to Government Decree 8/2006 & $\begin{array}{l}2=\text { On time } ; 1=\text { Other; } \\
0=\text { No Information }\end{array}$ \\
\hline 6. & $\begin{array}{l}\text { Regulation of local government financial management according to Government } \\
\text { Decree No.58/2005 }\end{array}$ & $\begin{array}{l}2=\text { Exist; } 1=\text { Non-exist; } 0= \\
\text { No information }\end{array}$ \\
\hline 7. & Follow Up of Audit Recommendation & Percentage $(\%)$ \\
\hline 8. & Standard Operating Procedure & Percentage $(\%)$ \\
\hline 9. & Development Planning Documents & Percentage $(\%)$ \\
\hline 10. & Financial Statements Component & Percentage (\%) \\
\hline 11. & Inventory Lists & Percentage $(\%)$ \\
\hline 12. & Number of Unused Assets & Percentage $(\%)$ \\
\hline
\end{tabular}

\section{Descriptive Statistics}

The local governments that have complete data for 2010-2015 amounted to 2,108 firm year observation. The majority of audit opinions of local governments are qualified opinions. In terms of the on-time submission of mandatory reports, on average, half of the local governments submitted their financial statements, budgets and performance reports on time. Nevertheless, this number still requires improvement. Central government has already equipped local governments with regulations regarding financial management and it has been proven that approximately $90 \%$ of the local governments are aware of these regulations. The percentage of follow-ups to audit recommendations is $68 \%$, which is consistent with previous research ${ }^{9,10,20}$. The percentage of local governments with standard operating procedures is still low (44\%) but the percentage of local governments with complete development planning documents, financial statements and inventory lists is quite high (above 70\%).

Table.2. Component of Accountability Index

\begin{tabular}{ll}
\hline \multicolumn{1}{c}{ Component } & \multicolumn{1}{c}{ Variables } \\
\hline $\begin{array}{l}\text { Administrative } \\
\text { Accountability }\end{array}$ & $\begin{array}{l}\text { Existence of Development Planning Documents } \\
\text { Complete financial statement component } \\
\text { Complete Inventory List }\end{array}$ \\
$\begin{array}{l}\text { Report Timeliness } \\
\text { (RPTTM) }\end{array}$ & $\begin{array}{l}\text { On time Submission of Financial Statement according Government Decree No 8/2006 } \\
\text { On time Submission of Performance Report according to Government Decree 8/2006 } \\
\text { On time Submission of LPPD according to Government Decree No 3/2007 }\end{array}$ \\
& $\begin{array}{l}\text { On time Budget (APBD) enactment } \\
\text { Existence of Regulation of local government financial management according to } \\
\text { Government Decree No.58/2005 }\end{array}$ \\
& $\begin{array}{l}\text { Follow Up of Audit Recommendation } \\
\text { Financial Accountability }\end{array}$ \\
(FACCT) & Standard Operating Procedure \\
& Unused asset*
\end{tabular}

*) An unused asset has negative sign or has inverse effect on accountability

Based on those three components, the score of accountability index will be measured using the formula below:

$$
\text { ACCTINDEX }=0.5251 \text { ADMAT + 0.272 RPTTM + 0.2029 FACCT }
$$

Using the ACCTINDEX formula, we classify our sample into quartiles. We found that only $25 \%$ of our sample falls into the top quartile of the accountability index. This result is important, highlighting that the other local governments still score low for accountability.

In order to answer the second research question, we use a subsample to test the relationship between

\footnotetext{
${ }^{i}$ Magnitude of the coefficient is derived from total variance explained of each component in PCA
} 
accountability indexes and corruption. The data is reduced since the corruption data from the Corruption Eradication Commission is not complete. We define corruption as the number of public complaints regarding corruption cases. The Corruption Eradication Commission will follow up these public complaints to the investigation level. We also control the regression with some control variables of a human development index, number of work units and total revenue $e^{12,20}$. The regression result can be seen in Table 3 .

Table.3. Regression Analysis Result

\begin{tabular}{cccc} 
CORRUPT $_{i t}=\mathrm{a}_{0}+\beta_{2} \mathrm{HDI}_{i t}+\beta_{3} \mathrm{COMPLEX}_{i t}+\beta_{4} \mathrm{LOGREV}_{i t}+\varepsilon_{i t}$ & \\
\hline Variables & Exp Sign & Coeff & Sig \\
\hline LACCTINDEX & - & -1.76 & $0.056^{*}$ \\
HDI & - & 0.185 & 0.276 \\
COMPLEX & + & -0.023 & 0.308 \\
LOGREV & + & 26.878 & $0.000^{* * *}$ \\
CONS & & -326.528 & 0.000 \\
\hline
\end{tabular}

Prob $>$ F (F-test $)=0,0000$

R-squared $=0,3494$

$\mathrm{N}=129$

Notes:

CORRUPT: number of public complaints on corruption | LACCTINDEX: lack of accountability index | HDI: Human Development Index | COMPLEX: number of local government work unit | LOGREV: $\log$ of total revenues | *** significance at $\left.1 \%\right|^{* *}$ significance at $\left.5 \%\right|^{*}$ significance at $10 \%$

Analyzing Table 3, we can see that an accountability index has a negative effect on corruption. This result is consistent with previous research ${ }^{17,16.18}$. As one of the good public governance principles, accountability is associated with lower corruption and it is still an effective strategy in developing countries such as Indonesia.

Higher accountability will have a negative relationship with corruption ${ }^{13}$. In the model, we use a comprehensive accountability index as the main variable. The additional test is carried out by using a breakdown of the component of an accountability index and testing its relationship with corruption. The result shows that, of all three components, administrative accountability and financial accountability have a negative relationship with corruption. This result implies that local governments need to increase their administrative and financial accountability in order to reduce corruption.

\section{CONCLUSION}

The purpose of this paper is to develop a comprehensive accountability index for Indonesia's local governments and to provide evidence of the relationship between an accountability index and corruption. In previous research, accountability was measured using a single measure, such as using follow-ups to audit recommendations or audit opinions. Using data from the Ministry of Internal Affairs' score in respect of local government performance (EKPPD) from 2010 to 2015, we identify several measures that match the accountability criteria. Principal component analysis is used to reduce twelve variables to three major components of accountability: administrative accountability, report timeliness and financial accountability. From these three components, we create the accountability index that represents a comprehensive measurement of local government accountability. We then use the accountability index to test the relationship between accountability and corruption. The result shows that a higher accountability index is associated with lower corruption.

The important implication of the study is that local governments can measure their level of accountability by using the score of Local Government Performance Report that they submit annually to the Ministry of Internal Affairs. Local governments are encouraged to increase their accountability, especially their administrative and financial accountability, as this has been proven in this study to have an effect in reducing corruption. For the researcher, the accountability index proposed in this study can be one of the best alternatives for measuring accountability rather than using a single measure.

The study has several limitations. First, it is an early study in terms of developing an accountability index. The variables used to match the accountability criteria are only based on a general accountability principle from KNKG. Further research could consider supporting the variable selection with more thorough research and using a panel of experts. Second, the regression test only uses a subsample with limited data. Further research should consider completing all data and adding an additional control corruption variable. 


\section{REFERENCES}

[1] Republik Indonesia. Peraturan Presiden No. 81 Tahun 2010 tentang Grand Design Reformasi Birokrasi 2010-2025, Sekretariat Negara, Jakarta, (2010).

[2] IFAC. International framework: good governance in the public sector, Downloaded from https://www.ifac.org/publicationsresources/international-framework-good-governance-public-sector (2014).

[3] Komite Nasional Kebijakan Governance. Pedoman Good Public Governance, Downloaded from http://www.knkgindonesia.org/dokumen/Pedoman-Good-Public-Governance.pdf (2008).

[4] Republik Indonesia. Peraturan Pemerintah No. 8 Tahun 2006 tentang Pelaporan Keuangan dan Kinerja Instansi Pemerintah. Sekretariat Negara. Jakarta, (2006).

[5] Supreme Audit Institution. Summary of audit report BPK $2^{\text {nd }}$ semester, (2016).

[6] D. Afriyanti, H. G. Sabanu, and F. Noor. Measurement of government institution accountability index, Jurnal Tata Kelola \& Akuntabilitas Keuangan Negara 1(1) (2015) 21-42.

[7] M. C. Jensen, and W. H. Meckling. Theory of the firm: managerial behavior, agency costs and ownership structure, Journal of Financial Economics 3(4) (1976) 305-360.

[8] K. L. Hofheimer. The good governance agenda of international development institutions. Diss. Old Dominion University, Virginia, (2006).

[9] P. W. Ekasani. The effect of fiscal decentralization and accountability of financial statements to the level of corruption of local governments in Indonesia, Thesis (Unpublished), (2016).

[10] D. Setyaningrum, L. Gani, D. Martani, and C. Kuntadi. The effect of auditor quality on the follow-up of audit recommendation, International Research Journal of Business Studies, 6(2) (2015) 89-104.

[11] J. Liu and L. Bin. Government auditing and corruption control: evidence from China's provincial panel data. China Journal of Accounting Research, 5 (2012).

[12] K. Azhar and D. Setyaningrum. The effect of audit findings and the follow up of audit recomendation on corruption of ministries/institutions in Indonesia, Presented in AAAA Annual Conference, Bandung, (2015).

[13] R. Klitgaard. Controlling corruption. University of California Press, California, (1988).

[14] V. Tanzi. Corruption around the world: causes, consequences, scope, and cures, Staff Papers, 45(4) (1998) 559-594.

[15] R. Fisman and R. Gatti. Decentralization and corruption: evidence across countries, Journal of Public Economics, 83(3) (2002) 325345.

[16] T. V. Nguyen, T. N. Bach, T. Q. Le, and C. Q. Le. Local governance, corruption, and public service quality: evidence from a national survey in Vietnam, International Journal of Public Sector Management, 30(2) (2017) 137-153.

[17] D. Kaufman. Myths about governance and corruption, Finance and Development, 42(3) (2005) 10.

[18] A. Wells-Dang, K. T. Le, and T. L. Nguyen. Between trust and structure: citizen participation and local elections in Vietnam, Vietnam, August (2015).

[19] R. A. Johnson and D. W. Wichern. Applied multivariate statistical analysis, Prentice Hall, London, (2002) 265.

[20] R. D. P. Amrih. Effects of governance and e-government on corruption probability, Thesis (Unpublished), (2016). 